\title{
DETERMINATION OF INHIBITORS OF UROKINASE- ACTIVATED FIBRINOLYTIC ENZYME SYSTEM BY MEANS OF GEL FILTRATION IN HUMAN SERUM
}

\author{
KAZUYA YAMAMOTO, TAKAMURA MURAKI* and IWAO FUKUI \\ Department of Dermatology, the National Children's Hospital, \\ Tokyo, Japan
}

(Received for publication April 9, 1966)

\begin{abstract}
There are two groups in the inhibitors of fibrinolytic enzyme system: antiplasmins, the direct inhibitors of the enzyme; and the inhibitors of activators, such as the antistreptokinase, the antiurokinase and the inhibitors of tissue kinases. Moreover, several synthetic compounds such as EACA and AMCHA are also capable of inhibiting fibrinolysis. ${ }^{1}$

Since the nature of the inhibitors and the mechanism of their action were poorly clarified, our attempts in the isolation, purification, and characterization of the inhibitors in human serum were performed.
\end{abstract}

\section{MATERIALS AND METHODS}

Human serum: Venous blood was obtained from the antecubital vein. The blood was allowed to clot and the serum was separated after centrifugation.

Inhibitors solution: Human serum of $0.5 \mathrm{ml}$ was diluted 20 fold with distilled water, and the solution was adjusted to $\mathrm{pH} 5.2$ with glass electrode by adding $1.0 \%$ acetic acid with constant stirring. After centrifugation at 3,000 r.p.m. for $15 \mathrm{~min}$ at $4^{\circ} \mathrm{C}$, the supernatant was separated for the test. The pH of the supernatant was again adjusted to 7.4 by adding $0.5 \% \mathrm{NaOH}$ with same method. Five $\mathrm{ml}$ of this solution was placed on the gel bed.

Gel filtration method: Gel filtration was performed by method described previously.2) However, a column was $20 \mathrm{~mm}$ in diameter and $500 \mathrm{~mm}$ in height, and effluent was collected in $3.5 \mathrm{ml}$ portions.

* Department of Dermatology, School of Medicine, Keio University. Reprint requests to the National Children's Hospital, 3-35-31 Taishido, Setagaya$\mathrm{ku}$, Tokyo. 
Determination of protein concentration: Protein concentration of the fractions was determined by the modified Folin method. ${ }^{3)}$

Determination of antifibrinolytic activity: The fibrin clot lysis time by urokinase-activated fibrinolytic enzyme system was measured.45)6)

Effluent $(0.5 \mathrm{ml})$ of each fraction tube was mixed with $0.1 \mathrm{ml}$ of urokinase normal saline solution $(50 \mathrm{u} / \mathrm{ml}$, Midori), and then $0.05 \mathrm{ml}$ of thrombin solution $(100 \mathrm{u} / \mathrm{ml}$, Mochida) and $0.3 \mathrm{ml}$ of $0.33 \%$ fibrinogen solution (Armour) were added at $0^{\circ} \mathrm{C}$. The time (in minutes) required for the complete lysis of the formed clot at $37^{\circ} \mathrm{C}$ was measured, and the reciprocal of the lysis time $\times 10^{3}$ was tentatively defined to be the indicator of the activity of inhibitors in the original effluent of $0.5 \mathrm{ml}$. So the low value of the indicator means an increased antifibrinolytic activity in certain fraction.

As a control, $0.5 \mathrm{ml}$ of $0.1 \mathrm{M}$ Tris-HCl buffer (in $0.2 \mathrm{M} \mathrm{NaCl}$ ) was used instead of $0.5 \mathrm{ml}$ of effluent.

\section{RESULTS AND DISCUSSION}

The typical patterns of protein distribution and of antifibrinolytic activity were shown in Fig. 1. The serum of a 10-months-old boy without any allergic disorders and blood transfusion was examined.

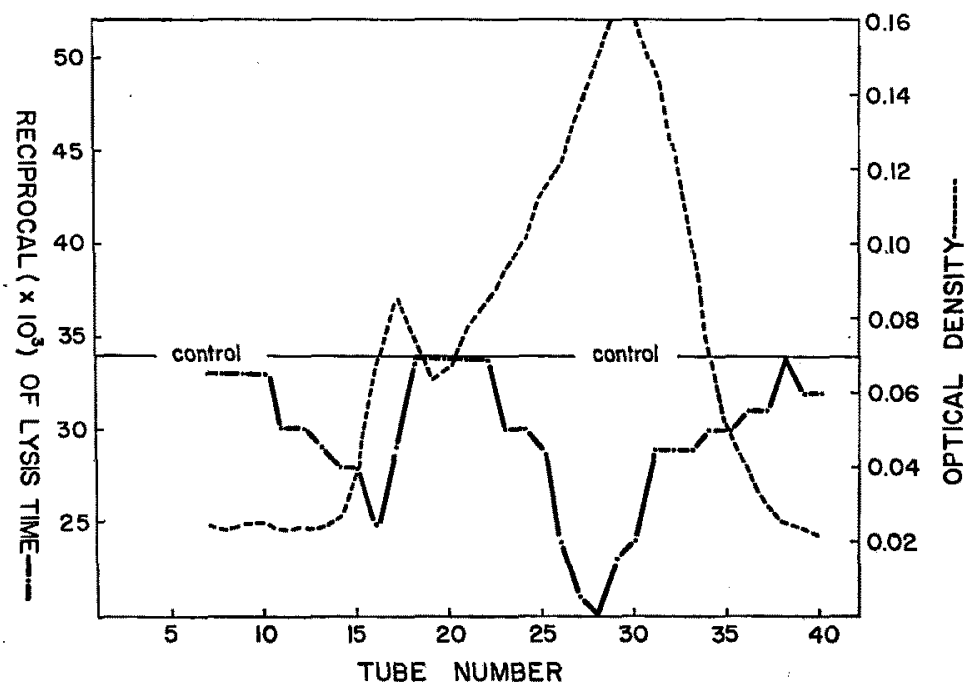

Fig. 1

In the experiment it was demonstrated that fractionation of the inhibitors solution could be obtained by a simple chromatographic procedure utilizing 
Sephadex G-200. The general elution pattern showed separation into two main peaks. Further identification of the material in the peaks was not attempted. According to Flodin and Killander, ${ }^{7}$ however, in the first peak $\alpha_{2}$-macroglobulin and $\alpha$ - $\beta$-lipoproteins were identified, and the 7-S $\gamma$-globulin was found in the second peak and albumin and transferrin in the third peak in case of human sera. Since the inhibitors solution was fractionated in our investigation, the first peak was identified as their first peak and the second peak was considered as their third peak.

As also shown in Fig. 1, by adopting our method the antifibrinolytic activity of the fractions showed following distribution; there were two kinds of ravines of the indicator, one was distributed between fraction number 10 to 18 , and another was found between 23 to 37 .

There were two peaks in the protein distribution, and two ravines were also found in the curve representing the reciprocal of the lysis time. Since the experimental system used contained enough plasminogen, the curve has a distinct relation to the concentration of inhibitors in the effluent. Inhibitor found in the earlier fractions was named as $\alpha$-inhibitor and that in the later fractions as $\beta$-inhibitor tentatively.

In 1964 Takada, Takada and Okamoto's reported the fractionation of plasminogen activator and proactivator in tissue and blood by gel filtration. They found that there are two kinds of proactivators in the normal human plasma, proactivator $A$ and proactivator $B$. The localization of these proactivators are almost similar to the distribution of $\alpha$-and $\beta$-inhibitor incidentally.

According to Pechet ${ }^{8)}$ increased blood antiplasmin levels were clinically observed in acute venous and arterial thrombosis, acute myocardial infarction, uremia, pulmonary edema, after hemorrhage, in familial hyperlipemia, lipidstorage disease, maladsorption and thyrotoxicosis. The antiplasmin levels were found to be normal or dimnished in hepatitis, cirrhosis, polycythemia vera, myelofibrosis, leukemia, neoplasms with metastasis, arterioselerosis and hypercholesterolemia. Diminished levels of inhibitors of the activation mechanism and antiplasmin are invariably seen in pathologic fibrinolysis.

As the method to clarify the significances of these clinical evidences gel filtration is considered to be useful, therefore further attempts to investigate these inhibitors with the technique described above are being carried out.

\section{SUMMARY}

New method for determination of blood antifibrinolytic activity by means of gel filtration was discussed.

1) Fractionation of antifibrinolytically active components of blood was performed. 
2) There are two kinds of inhibitors to urokinase-activated fibrinolytic enzyme system in normal human serum, $\alpha$-inhibitor and $\beta$-inhibitor.

\section{ACKNOWLEDGEMENTS}

Read before the 432nd meeting of the Tokyo Dermatological Society on March 19, 1966 in Tokyo. The assistance of the staff of Department of Physiology, School of Medicine, Keio University, is gratefully acknowledged. This work was supported in part by a grant from the Waksman Foundation of Japan Inc.

\section{REFERENCES}

1. Okamoto, S. et al.: Keio J. Med., 13: 177, 1964.

2. Yamamoto, K. et al.: ibid., 13: 195, 1964.

3. Lowry, O. H. et al.: J. Biol. Chem., 193: 265, 1951.

4. Takada, A. et al.: Keio J. Med., 13: 187, 1964.

5. Yamamoto, K. et al.: ibid., 14: 107, 1965.

6. Takada, Y. et al.: ibid., 14: 161, 1965.

7. Flodin, P. and Killander, J.: Biochim. Biophys. Acta, 63: 403, 1962.

8. Pechet, L.: New England J. Med., 273: 966, 1965. 